\title{
Effects of reduced UV radiation on a microbenthic community during a microcosm experiment
}

\author{
Raphaël Roux ${ }^{1}$, Michel Gosselin ${ }^{1, *}$, Gaston Desrosiers ${ }^{1}$, Christian Nozais ${ }^{2, * *}$ \\ ${ }^{1}$ Institut des sciences de la mer de Rimouski (ISMER), Université du Québec à Rimouski, 310 allée des Ursulines, \\ Rimouski, Québec G5L 3A1, Canada \\ ${ }^{2}$ School of Life and Environmental Sciences, University of Natal, King George V Avenue, Durban 4041, South Africa
}

\begin{abstract}
A microcosm experiment was conducted over a 77 d period (from 6 July to 21 September 1999) to investigate the response of a microbenthic community to the long-term reduction of ambient ultraviolet-B (UVBR, 280 to $320 \mathrm{~nm}$ ) and ultraviolet-A (UVAR, 320 to $400 \mathrm{~nm}$ ) radiation. Intact sediment cores were harvested from a muddy intertidal flat in the lower St. Lawrence Estuary (Quebec, Canada) and placed in an outdoor flow-through system under 3 treatments: ambient solar radiation, reduced UVBR and reduced UVR (280 to $400 \mathrm{~nm}$ ). Both autotrophic (primary production, microalgal biomass, accessory pigments, diatom composition and abundance and UVR absorbing compounds) and heterotrophic (meiofaunal abundance) components were investigated. It was found that neither nematode nor ontogenic stages of harpacticoid copepod abundances were affected by the treatments. The temporal variations of the nauplius, copepodite and copepod populations correspond to the normal ontogenic evolution of harpacticoids. The microphytobenthic community, dominated by small $(\leq 15 \mu \mathrm{m})$ pennate diatoms, presented significantly higher carbon fixation under UVR protected treatments on Days 14 and 21, suggesting a simultaneously detrimental but weak effect of UVBR and UVAR on photosynthesis. Occurring in very low concentrations in the sediment, UVR absorbing compounds did not seem to be a major UVR-attenuation mechanism within the microbenthic community. The screening of UVBR and UVR also resulted in a stepwise decrease of microalgal biomass on Days 7, 21, 28, 35 and 42, and of diatom abundance on Day 35. The simultaneous accumulation of pheopigments likely reflected an enhanced grazing pressure under both UVshielded treatments, presumably by microfaunal grazers. The fact that these noticeable changes were observed between the 3 treatments implies that both UVBR and UVAR influence the microphytobenthic community. There was a lack of treatment effect during the second half of the experiment when UVR fluxes showed their normal seasonal decrease. Thus, our results indicate that effects of ambient UVR on microbenthos occur only under high solar irradiance. During this period, both ambient UVBR and UVAR exerted a controlling effect on the microalgal standing stock in muddy intertidal flats in the lower St. Lawrence Estuary.
\end{abstract}

KEY WORDS: Intertidal mudflat $\cdot$ Microphytobenthos $\cdot$ Meiofauna $\cdot$ St. Lawrence Estuary $\cdot$ UV radiation $\mathrm{A}$ and $\mathrm{B}$

\section{INTRODUCTION}

Solar radiation is a fundamental ecological factor in aquatic and terrestrial ecosystems. The ultraviolet-B component (UVBR, 280 to $320 \mathrm{~nm}$ ) of the solar spectrum is mainly absorbed by stratospheric ozone. In the past years, a decrease of the ozone layer has been discovered over Antarctica (Farman et al. 1985, Hofmann
1996, Randel \& Wu 1999), the Arctic (Müller et al. 1997, Rex et al. 1997, Randel \& Wu 1999) and temperate latitudes (Blumthaler \& Ambach 1990, Kerr \& McElroy

\footnotetext{
${ }^{*}$ Corresponding author. E-mail: michel_gosselin@uqar.qc.ca ${ }^{* *}$ Present address: ISMER, Université du Québec à Rimouski, 310 allée des Ursulines, Rimouski, Québec G5L 3A1, Canada
} 
1993). The resulting enhanced UVBR has long been recognized as a significant and pervasive selective force on aquatic organisms (Vincent \& Roy 1993) and therefore on ecosystems (e.g. Mostajir et al. 2000).

The last decade has stressed a great deal of progress in the understanding of the biological effects of UVBR. Less research has been directed toward the effects of ultraviolet-A radiation (UVAR, 320 to $400 \mathrm{~nm}$ ). However, since this component of the solar spectrum comprises a substantial proportion of the total ultraviolet radiation (UVR, 280 to $400 \mathrm{~nm}$ ) energy, UVAR could be found to be equally damaging as UVBR. Solar UVAR has been shown to have a wide range of harmful effects on phytoplankton photosynthesis (Helbling et al. 1992, Arrigo 1994, Moeller 1994) and bacterioplankton activity (Sommaruga et al. 1997).

Biologically effective levels of solar UVR penetrate the water column to significant depths (Kirk 1994). Although shallow-water benthic communities can be particularly sensitive to UVR, their response is not uniform and varies as a result of temporal and spatial disparity of both UVR exposure and organism sensitivity (Hill et al. 1997). UVBR exposure can be responsible for a decrease in periphytic biomass (Vinebrooke \& Leavitt 1996) and benthic primary production (Sundbäck et al. 1997, Odmark et al. 1998), and a shift in the species composition of algal communities (Santas et al. 1997, Vinebrooke \& Leavitt 1999). UVAR, in addition to UVBR, is also known to disrupt the balance between primary producers and consumers in streams (Bothwell et al. 1994).

Investigations dealing with the UV-response of natural, intact microphytobenthic communities inhabiting intertidal flats are scarce. Yet, benthic microalgae colonizing these ecosystems serve crucial ecological function (MacIntyre et al. 1996, Underwood \& Kromkamp 1999). They play a key role in sediment stability and geochemistry and provide a major food source for invertebrate grazers, particularly meiofauna (Miller et al. 1996). The aerial exposure of sediment at low tide permits UVR to penetrate at significant depths in sediment. For example, Wulff et al. (1999) reported a potential light penetration depth $(1 \%)$ in dry sediment of 1100 to $1200 \mu \mathrm{m}$ for photosynthetically active radiation, PAR (at $650 \mathrm{~nm}), 500$ to $800 \mu \mathrm{m}$ for UVA (365 nm) and 400 to $600 \mu \mathrm{m}$ for UVB (310 nm). In addition, high photosynthetic rates under solar exposure can lead to the production of reactive oxygen species, provoking additional indirect damage (Garcia-Pichel \& Bebout 1996). During a 6 wk long microcosm experiment, Nozais et al. (1999) showed that the overall intertidal meiobenthic community of the St. Lawrence Estuary was sensitive to ambient levels of UVBR. However, conclusions about the long-term ecological impacts of UVR cannot be forecast from short-term results
(Bothwell et al. 1993). The present study aimed to determine the long-term $(77 \mathrm{~d})$ effects of reduced UVBR and reduced UVR (reduced UVBR and UVAR) on the microphyto- and meiozoobenthos inhabiting a muddy intertidal flat. The specific objectives were to: (1) assess the sensitivity of microphytobenthos (primary production and biomass, accessory pigments and diatom composition and abundance) to $\mathrm{UVR}_{i}(2)$ examine the photoprotection level (UVR-absorbing compounds) of the community; and (3) investigate the direct effects of UVR on meiofauna abundance. We focussed on nematodes and ontogenic stages of harpacticoid copepods as these 2 taxonomic groups account for more than $95 \%$ of the total abundance of meiofauna at the sampling site (Tita 1999). Conducted over nearly $3 \mathrm{mo}$, the experiment was expected to be long enough to detect effects of UVR reduction on the dynamics of the microphytobenthic community and associated meiofauna.

\section{MATERIALS AND METHODS}

Experimental set-up. The experiment was carried out at the Station aquicole de Pointe-au-Père of the University of Quebec at Rimouski, on the south shore of the lower St. Lawrence Estuary, Canada (48 31' N, $68^{\circ} 28^{\prime} \mathrm{W}$ ) from 6 July to 21 September 1999. A microcosm approach was adopted using an outdoor flowthrough system consisting of 9 plastic microcosms (44 l) and a $800 \mathrm{l}$ plastic tank containing filtered seawater (using a serial filtering of cotton cartridge filters of 50, 5 and $1 \mu \mathrm{m}$ ). A pump inside the tank (Little Giant Pump Co., Oklahoma City, OK; flow rate of $74 \mathrm{l} \mathrm{h}^{-1}$ ) distributed the filtered seawater within every microcosm. A semi-diurnal tide traced from the natural tidal cycle allowed the seawater to increase from $1 \mathrm{~cm}$ (low tide) to $10 \mathrm{~cm}$ (high tide) above the sediment surface. The filtered seawater in the tank was changed every day, just before the slack of the natural low tide. Consequently, the water entering into the microcosms during the flood tide was completely renewed. Water temperature and salinity in the microcosms were recorded during the water renewal. Salinity was determined with a hand held salinity refractometer (Vista Series Instruments A366ATC).

Three light treatments (control, reduced UVBR and reduced UVR) were achieved by covering microcosms with UVR-transparent acrylic sheets (OP-4, Plastic Alto Inc., Quebec City, Canada; 4.76 mm thick), Mylar-D films (Cadillac Plastic Inc., Montreal, Canada; $0.13 \mathrm{~mm}$ thick) and UF-4 filters (Plastique Alto Inc., Quebec City, Canada; $4.76 \mathrm{~mm}$ thick) respectively. Spectral transmission properties of all these filters are presented in Fig. 1. Mylar-D sheets were changed every 
week in order to avoid modification in transmission properties due to photodegradation. Treatments were carried out in triplicate.

Light measurements. Throughout the experiment, an IL 1700 radiometer (International Light, Newburyport, MA) recorded incident downwelling solar irradiance next to the experimental device. UVBR, UVAR and PAR (400 to $700 \mathrm{~nm}$ ) were measured using SUD240/SPS300/W, SUL033/UVA/W and SUL033/PAR/ W/QNDS1 flat photodetectors, respectively. The unweighted spectral irradiance at the water surface was calculated under the 3 treatments. For this calculation, we used incident irradiance data measured every nanometer from 280 to $400 \mathrm{~nm}$ with an OL $754 \mathrm{spec}-$ troradiometer (Optronic Laboratories, Orlando, FL; see Whitehead et al. 2000 for more details). To estimate the biological importance of UVR reduction on photosynthesis, irradiance was also weighted by the biological weighting function (BWF) for inhibition of photosynthesis in Phaeodactylum of Cullen et al. (1992).

Study area and sampling methods. The sampling site was located in the intertidal zone of Anse à l'Orignal in the Parc national du Bic $\left(48^{\circ} 20^{\prime} \mathrm{N}, 68^{\circ} 48^{\prime} \mathrm{W}\right)$, $30 \mathrm{~km}$ west of the Station aquicole de Pointe-au-Père. The intertidal flat extends over $2 \mathrm{~km}^{2}$ and faces northeast. Hydrodynamic processes depend on the semidiurnal tide $\left(\mathrm{M}_{2}\right.$ Godin 1979) that provides a mesotidal regime. In summer, the maximum water height and the mean water clarity (as determined by transmissivity) in this cove varied from 71 to $311 \mathrm{~cm}$ and from 61 to $80 \%$, respectively (Thorin et al. 1998). The colonized layer of the sampling area (i.e. the layer overlying a Godthwait clay deposit, Dionne 1977) consists of a sandy mud with $2 \%$ of organic matter (Tita 1999), covered with a 1 to $2 \mathrm{~mm}$ thick cohesive microbial mat. On 5 July, 108 intact sediment cores were collected using transparent plexiglas corers (inner diameter $68 \mathrm{~mm}$, height $80 \mathrm{~mm}$ ) and then randomly placed inside the microcosms (12 cores per microcosm). Using intact sediment cores permits the maintenance of the complex trophic network of the microbenthic community. A careful daily inspection of sediment cores allowed us to remove macrofauna (e.g. the gastropods Hydrobia minuta and polychaetes Nereis virens) occurring at the sedimentwater interface. On each sampling date, that is every week from 6 July, a core was randomly removed from each microcosm and sediment samples were taken with circular syringes of $9 \mathrm{~mm}$ inner diameter. Samples for primary productivity, microalgal biomass and meiofauna were collected every week whereas those for particulate organic matter, diatom composition and abundance, accessory pigments and UVR-absorbing compounds were taken 3 times (Days 0, 35 and 77). The top 2 to $3 \mathrm{~mm}$ of the syringes were retained for laboratory analysis, except that meiofauna abundance

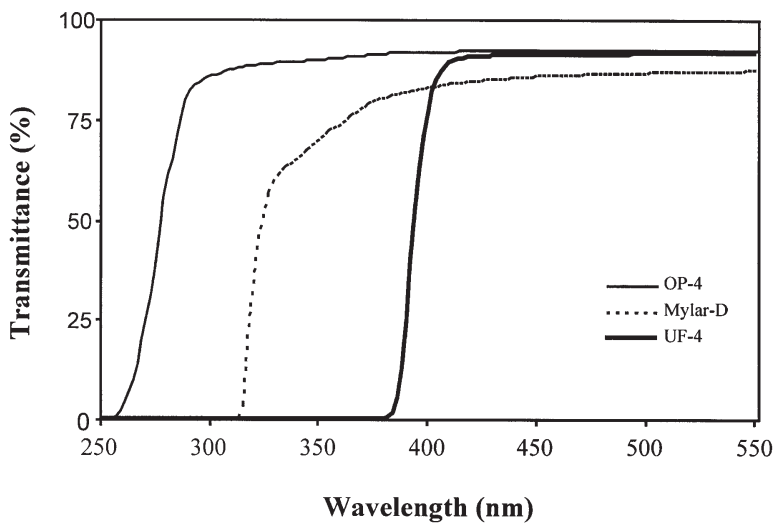

Fig. 1. Transmission spectra of OP-4, Mylar-D and UF-4 filters fixed over microcosms

was quantified from the upper $2 \mathrm{~cm}$ since $90 \%$ of meiofauna are concentrated within this depth (Tita 1999).

Inorganic nutrients and total organic carbon. Concentration of ammonium $\left(\mathrm{NH}_{4}{ }^{+}\right)$, nitrate and nitrite $\left(\mathrm{NO}_{3}{ }^{-}+\mathrm{NO}_{2}^{-}\right)$, silicic acid $\left(\mathrm{Si}(\mathrm{OH})_{4}\right)$ and phosphate $\left(\mathrm{PO}_{4}{ }^{3-}\right)$ were measured every week from samples collected in the overlying water of each microcosm. Samples were immediately filtered on precombusted Whatman GF/F glass-fiber filters before being deepfrozen $\left(-80^{\circ} \mathrm{C}\right) . \mathrm{NH}_{4}{ }^{+}$concentration was determined according to the method of Solórzano (1969) as described by Parsons et al. (1984). The other inorganic nutrients were measured using a Technicon Autoanalyzer II (Strickland \& Parsons 1972). For total organic carbon (TOC) measurements, duplicate samples were collected from the common water exit of the microcosms in $4 \mathrm{ml}$ glass storage vials with Teflon-lined caps previously cleaned following the protocol of Burdige \& Homstead (1994). The samples were acidified to $\sim \mathrm{pH} 2$ with $50 \% \mathrm{v} / \mathrm{v} \mathrm{H}_{3} \mathrm{PO}_{4}\left(5 \mu \mathrm{ml}^{-1}\right)$. TOC was determined on a TOC-5000 analyzer (Shimadzu, Kyoto, Japan) using the analysis procedure given in Whitehead et al. (2000).

Particulate organic matter. One sample was taken from each core and immediately stored at $-20^{\circ} \mathrm{C}$ for later determination of particulate organic carbon (POC) and nitrogen (PON). Samples were dried at $60^{\circ} \mathrm{C}$ for $24 \mathrm{~h}$ and pelletized before quantification with a Model 2400 CHN analyzer (Perkin-Elmer, Wellesley, MA).

Microphytobenthos. For the determination of accessory pigments and UVR-absorbing compounds, 2 separate samples were immediately stored at $-20^{\circ} \mathrm{C}$ after sampling. All subsequent steps were done at dim light and room temperature. Extraction of pigments and UVR-absorbing compounds was performed in $98 \%$ methanol $/ 2 \%$ ammonium acetate. The extract was sonicated $(40 \mathrm{kHz}, 5 \mathrm{~min})$ and centrifuged $(3200 \mathrm{rpm}$, 
$2 \mathrm{~min})$. The extraction procedure was repeated once more. Both supernatants were pooled before being filtered on $0.2 \mu \mathrm{m}$ Acrodisc $^{\circledR}$ filters. A test showed that this technique extracts about $99 \%$ of the sediment pigment and UVR-absorbing compounds. Pigments were analyzed by reversed-phase high-performance liquid chromatography (HPLC) according to Wright et al. (1991) as modified by Roy et al. (1996), while the presence of UVR-absorbing compounds was determined using a Lambda 12 spectrophotometer (Perkin Elmer).

Immediately after sampling, 2 samples were pooled in $2 \%$ formaldehyde and stored at $4^{\circ} \mathrm{C}$ for the later enumeration and identification of the microalgae. The samples were diluted, and diatoms (empty and chloroplast-containing cells) were enumerated using the inverted microscope method (Lund et al. 1958). Diatoms were grouped into size and shape classes, and then identified when possible to genus level.

Microalgal biomass was based on chlorophyll a (chl a) concentration. After sampling, 2 syringes from each core were immediately frozen at $-20^{\circ} \mathrm{C}$. All subsequent manipulations were done at room temperature and dim light. The day after sampling, the frozen sediment was dried at $60^{\circ} \mathrm{C}$ for $24 \mathrm{~h}$. Chl a extraction was performed in $10 \mathrm{ml} 90 \%$ acetone and kept at $4{ }^{\circ} \mathrm{C}$ in the dark for $18 \mathrm{~h}$ (Riaux-Gobin \& Klein 1993). Fluorescence was measured before and after acidification with $5 \% \mathrm{HCl}$ on a R010 Turner Designs Fluorometer, for the determination of chl $a$ and pheopigment concentrations.

Benthic microalgal productivity was measured by the ${ }^{14} \mathrm{C}$-assimilation method. Two samples from each core were pooled in $50 \mathrm{ml}$ of filtered seawater (Whatman GF/F). The sample was mixed and $0.5 \mathrm{ml}$ of $\mathrm{NaH}^{14} \mathrm{CO}_{3}\left(10 \mu \mathrm{Ci} \mathrm{ml}^{-1}\right)$ was added. Three $15 \mathrm{ml}$ subsamples were distributed in 3 borosilicate scintillation vials ( 1 dark and 2 light bottles) and then incubated in a downward position for $2 \mathrm{~h}(12: 00$ to $14: 00 \mathrm{~h})$ in a microcosm covered with a UVR-transparent acrylic sheet (OP-4). The dark bottle contained $50 \mu \mathrm{Hl}^{10^{-5}} \mathrm{~mol} \mathrm{l}^{-1}$ DCMU (Legendre et al. 1983). This procedure gave us 2 estimates of primary productivity per microcosm. After incubation, dissolved organic carbon (DOC) released during the incubation period was quantified by filtering $3 \mathrm{ml}$ of the subsample on a $0.2 \mu \mathrm{m}$ syringe MFS filter. The remainder $(12 \mathrm{ml})$ was filtered on a Whatman GF/F filter. To remove non-incorporated ${ }^{14} \mathrm{C}$, $0.2 \mathrm{ml} 0.5 \mathrm{~N} \mathrm{HCl}$ (Lean \& Burnison 1979) and $0.5 \mathrm{ml} 6 \mathrm{~N}$ $\mathrm{HCl}$ were added respectively to vials containing the filters and the $\mathrm{DO}^{14} \mathrm{C}$ samples. Twelve hours later, $10 \mathrm{ml}$ of EcoLume (ICN Biochemicals ${ }^{\circledR}$ ) scintillation cocktail was added to the vials and samples were kept in the dark for $24 \mathrm{~h}$ before being counted using a LS 5801 liquid scintillation counter (Beckman Coulter, Fullerton, CA). The daily primary production rate was obtained by dividing the total particulate carbon uptake by the fraction of daily PAR received during the incubation.

Meiozoobenthos. Three samples from each core were immediately preserved in $4 \%$ formaldehyde, with subsequent addition of Rose Bengal. After a few months, each sample was passed firstly through a $500 \mu \mathrm{m}$ sieve, to exclude macrofauna, and then through a $63 \mu \mathrm{m}$ sieve to isolate the meiofauna. Meiofaunal organisms were sorted from sediment by centrifugation using Ludox-TM (Heip et al. 1985) and counted under a dissecting microscope.

Statistical analyses. Before undertaking the parametric statistical tests, the different variables were tested for normality of distribution (KolmogorovSmirnov test) and homogeneity of variance (Hartley test). When needed, data were ln-transformed (Underwood 1981). To reveal the effects of treatment, a nested ANOVA was run separately for each sampling week, using 2 or 3 replicate cores nested in the factor treatment (Underwood 1981). For primary productivity and diatom abundance, treatment effects were tested by a one-way ANOVA. A multiple comparison test of means (Tukey test) was used when significant differences ( $p \leq 0.05)$ were found between treatments. To infer relationships between variables, Spearman's rank correlations $\left(\mathrm{r}_{\mathrm{s}}\right)$ were also calculated.

\section{RESULTS}

\section{Light, temperature, salinity and nutrients}

UVR intensities under the various filters were measured during a sunny day around noon (Fig. 2A). Mylar-D and UF-4 filters reduced UVBR irradiance by 80.7 and $99.9 \%$, respectively, when compared to control (OP-4) whereas the relative reduction of UVAR under these 2 filters reached 18.5 and $86.6 \%$, respectively. The biological weighting function of Cullen et al. (1992) shows the biological significance of the wavelengths between 310 and $340 \mathrm{~nm}$ (Fig. 2B). Compared to the control, Mylar-D and UF-4 filters removed the biologically weighted UVBR by 86.7 and $99.9 \%$ and that of UVAR by 24.1 and $99.3 \%$, respectively.

The UVBR flat collector stopped transferring the incident UVBR data to the computer at the beginning of the experiment. To estimate the daily incident UVBR irradiance, daily incident UVAR was multiplied by the daily incident UVBR:UVAR ratio of 0.036 measured by Nozais et al. (1999) for the same site between 8 July and 19 August 1997. Since the Environment Canada monitoring station located in Montreal, Quebec (World Ozone and UV Radiation Data Centre, Environment Canada, Downsview, Ontario, Canada) provided evi- 
dence of a similar state of ozone layer over Montreal in the summers of 1997 and 1999, one can assume that the UVBR fluxes reaching the experimental enclosures were similar for these 2 summers. The weekly UVBR irradiance given here represents only an estimation of the weekly UVBR flux during the experiment.

During this 11 wk long experiment, high variations in downwelling irradiance occurred. Maximal incident irradiance over the experimental enclosures at noon on sunny days ranged between 1700 and $1900 \mu \mathrm{E} \mathrm{m}{ }^{-2} \mathrm{~s}^{-1}$ for PAR and 32 to $36 \mathrm{~W} \mathrm{~m}^{-2}$ for UVAR. During the sunny days, daily incident PAR reached $55 \mathrm{E} \mathrm{m}^{-2}$, while incident UVAR and estimated UVBR attained 1121 and $44 \mathrm{~kJ} \mathrm{~m}^{-2} \mathrm{~d}^{-1}$, respectively. During overcast days, incident irradiances drastically declined to $9 \mathrm{E} \mathrm{m}^{-2} \mathrm{~d}^{-1}$ for PAR, $146 \mathrm{~kJ} \mathrm{~m}^{-2} \mathrm{~d}^{-1}$ for UVAR and $6 \mathrm{~kJ} \mathrm{~m}^{-2} \mathrm{~d}^{-1}$ for UVBR. Weekly irradiances of PAR, UVAR and UVBR under the various filters decreased gradually during the experiment as a result of increasing cloud cover (especially during the last $3 \mathrm{wk}$ ) and decreasing day length as per seasonal trends (Fig. 3). The PAR:UVAR ratio remained relatively constant throughout the experiment.

During the whole experiment, the average water temperature, and therefore that of the sediment, was around $20^{\circ} \mathrm{C}$, varying from $32^{\circ} \mathrm{C}$ at noon in July to $9^{\circ} \mathrm{C}$ in early morning in September. The average water temperature during the period of incubation for primary production measurements ranged between 13 and $20^{\circ} \mathrm{C}$. Salinity varied from 18 to 30 , with a mean value of 25 .

The concentration of inorganic nutrients in the overlying water of the microcosms varied greatly throughout the experiment (Table 1). Starting with high initial values $\left(\mathrm{NO}_{2}^{-}+\mathrm{NO}_{3}^{-}=10.9 \mu \mathrm{M}, \mathrm{NH}_{4}^{+}=2.1 \mu \mathrm{M}\right.$, $\mathrm{Si}[\mathrm{OH}]_{4}=14.5 \mu \mathrm{M}$ and $\left.\mathrm{PO}_{4}{ }^{3-}=0.90 \mu \mathrm{M}\right)$, nutrient con- centration decreased drastically to reach low values that correspond to a generally nutrient-depleted sea surface in summer. Molar ratios of dissolved inorganic nitrogen (DIN) to $\mathrm{PO}_{4}{ }^{3-}$ and $\mathrm{DIN}$ to $\mathrm{Si}[\mathrm{OH}]_{4}$ also ex-
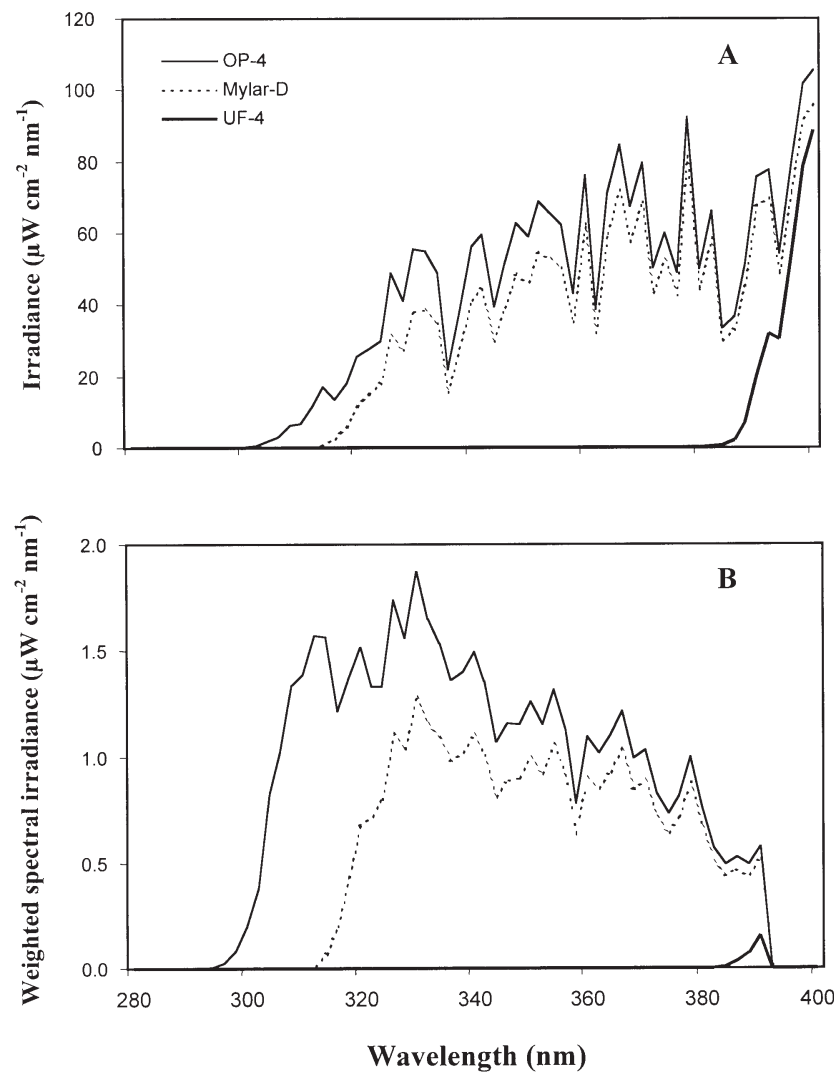

Fig. 2. UVR intensities under OP-4, Mylar-D and UF-4 filters during a sunny day around noon. (A) Unweighted spectral irradiance and (B) spectral irradiance weighted with the biological weighting function for the inhibition of photosynthesis in Phaeodactylum of Cullen et al. (1992)

Table 1. Average (SD) concentrations of nitrate and nitrite $\left(\mathrm{NO}_{3}{ }^{-}+\mathrm{NO}_{2}^{-}\right)$, ammonium $\left(\mathrm{NH}_{4}{ }^{+}\right)$, silicic acid (Si $\left.[\mathrm{OH}]_{4}\right)$, phosphate $\left(\mathrm{PO}_{4}{ }^{3-}\right)$, and ratios of dissolved inorganic nitrogen to phosphate (DIN: $\mathrm{PO}_{4}{ }^{3-}$ ) and of dissolved inorganic nitrogen to silicic acid (DIN:Si[OH $]_{4}$ ) in all the microcosms from Day 0 (6 July) to Day 77 (21 September)

\begin{tabular}{|c|c|c|c|c|c|c|}
\hline Day & $\begin{array}{c}\mathrm{NO}_{3}^{-}+\mathrm{NO}_{2}^{-} \\
(\mu \mathrm{M})\end{array}$ & $\begin{array}{l}\mathrm{NH}_{4}^{+} \\
(\mu \mathrm{M})\end{array}$ & $\begin{array}{c}\mathrm{Si}(\mathrm{OH})_{4} \\
(\mu \mathrm{M})\end{array}$ & $\begin{array}{c}\mathrm{PO}_{4}{ }^{3-} \\
(\mu \mathrm{M})\end{array}$ & $\begin{array}{l}\mathrm{DIN}: \mathrm{PO}_{4}{ }^{3-} \\
\text { (mol:mol) }\end{array}$ & $\begin{array}{c}\mathrm{DIN}: \mathrm{Si}(\mathrm{OH})_{4} \\
\quad(\mathrm{~mol}: \mathrm{mol})\end{array}$ \\
\hline 0 & $10.95(2.27)$ & $2.13(0.32)$ & $14.46(3.01)$ & $0.90(0.12)$ & $14.56(1.43)$ & $0.95(0.28)$ \\
\hline 7 & $0.44(0.18)$ & $0.42(0.27)$ & $9.63(2.15)$ & $0.24(0.03)$ & $3.63(1.32)$ & $0.09(0.05)$ \\
\hline 14 & $0.01(0.01)$ & $0.14(0.04)$ & $8.44(0.27)$ & $0.17(0.04)$ & $0.86(0.25)$ & $0.02(0.01)$ \\
\hline 21 & $5.29(1.23)$ & $0.46(0.08)$ & $15.53(1.43)$ & $0.57(0.11)$ & $10.15(0.32)$ & $0.37(0.07)$ \\
\hline 28 & $0.11(0.09)$ & $0.10(0.07)$ & $4.75(0.53)$ & $0.16(0.06)$ & $1.44(0.55)$ & $0.04(0.01)$ \\
\hline 35 & $0.57(0.15)$ & $0.04(0.02)$ & 4.96 (1.29) & $0.11(0.04)$ & $5.67(0.53)$ & $0.13(0.04)$ \\
\hline 42 & $0.93(0.52)$ & $0.03(0.04)$ & 5.59 (1.19) & $0.13(0.05)$ & $7.16(1.55)$ & $0.17(0.08)$ \\
\hline 49 & $0.39(0.21)$ & $0.03(0.03)$ & $7.30(1.55)$ & $0.17(0.03)$ & $2.30(1.33)$ & $0.05(0.03)$ \\
\hline 56 & $0.27(0.22)$ & $0.03(0.02)$ & $4.48(0.89)$ & $0.13(0.03)$ & $2.24(1.38)$ & $0.07(0.05)$ \\
\hline 63 & $2.09(0.62)$ & $0.08(0.04)$ & $3.82(0.92)$ & $0.46(0.12)$ & $4.70(0.42)$ & $0.58(0.23)$ \\
\hline 70 & $0.21(0.06)$ & $0.09(0.04)$ & $6.61(0.73)$ & $0.36(0.16)$ & $0.91(0.18)$ & $0.05(0.01)$ \\
\hline 77 & $0.03(0.03)$ & $0.14(0.08)$ & $3.39(0.54)$ & $0.03(0.03)$ & 6.29 (5.73) & $0.05(0.03)$ \\
\hline
\end{tabular}




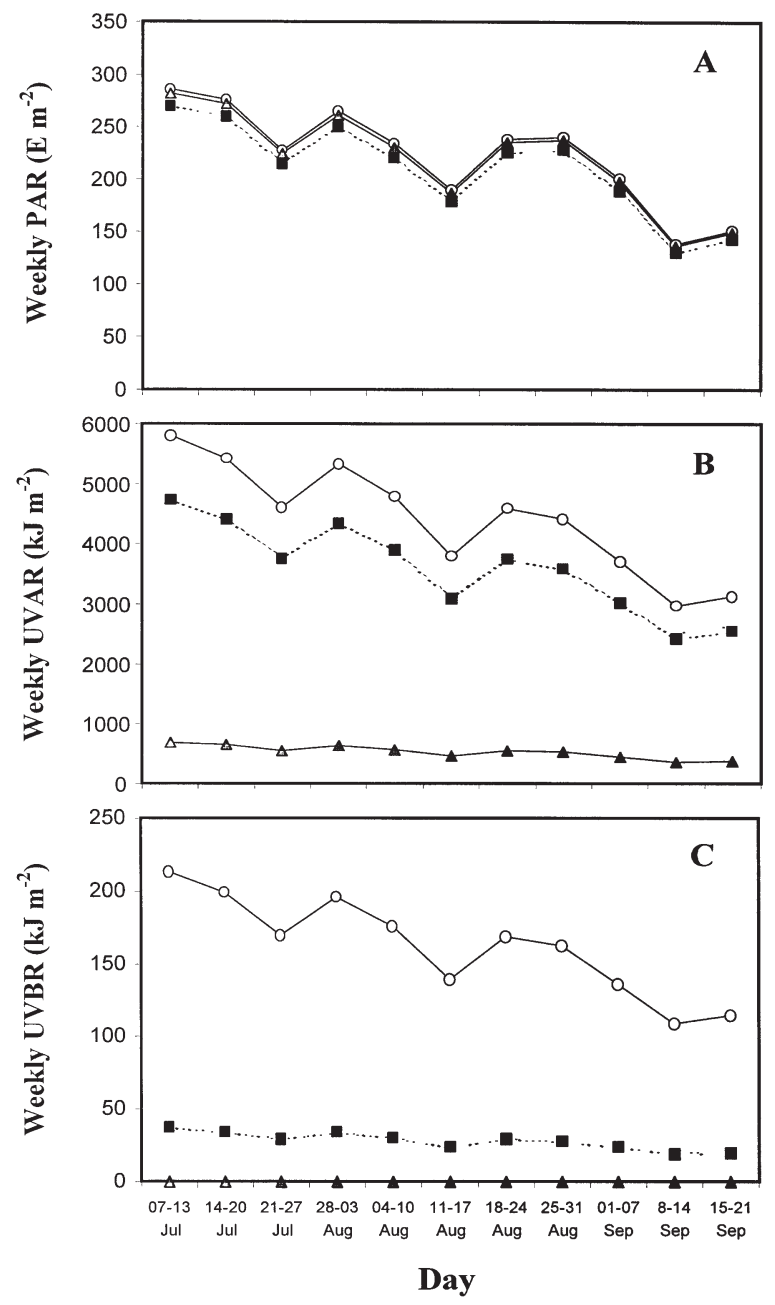

Fig. 3. Weekly variations of the (A) PAR, (B) UVAR and (C) UVBR components of the solar irradiance under OP-4 (control, O), Mylar-D (reduced UVBR, $\square$ ) and UF-4 (reduced UVR, ム) filters used during the experiment. UVBR values were assessed from the ratio of daily UVBR to daily UVAR provided by Nozais et al. (1999)

hibited great temporal variability, with values ranging from 0.9 to 14.6 and from 0.02 to 0.95 , respectively (Table 1). There was no significant relationship between inorganic nutrients and the other measured biological variables.

\section{TOC and particulate organic matter}

The concentration of TOC in the common water of all the microcosms ranged between 103 and $187 \mu \mathrm{M}$, with an average value of $161 \mu \mathrm{M}$. POC concentrations in the top 2 to $3 \mathrm{~mm}$ of the sediment remained rather constant throughout the experiment, ranging from 2682 to $2726 \mathrm{mgC} \mathrm{m}^{-2}$. The POC:PON molar ratio stayed around 11.5. No significant treatment effect on the concentrations of POC and nitrogen was found.

\section{Microphytobenthos}

HPLC pigment analysis revealed, in addition to chl a and degradation pigments, chlorophyll $C_{1+2}\left(\mathrm{chl} C_{1+2}\right)$ and the carotenoids fucoxanthin, diadinoxanthin, diatoxanthin, $\beta, \beta$-carotene and 19'-hexanoyloxyfucoxanthin. In each treatment, ratios of fucoxanthin to chl a and that of chl $C_{1+2}$ to $\mathrm{chl}$ a increased significantly over time, particularly during the second part of the experiment (Table 2). The different light treatments did not affect any accessory pigment to chl a ratios during the whole experiment, except that on Day 77 when reduced UVR resulted in an enhanced fucoxanthin:chl a ratio compared to the UVBR shielded treatment.

Microscopical examination revealed that diatoms were the main algal group in the sediment. Flagellates and cysts of Chrysophyceae were also observed. The diatom community was dominated by small $(\leq 15 \mu \mathrm{m})$ unidentified pennate diatoms (Fig. 4). The main identified diatoms belonged to the genera Cocconeis ( $\leq 25 \mu \mathrm{m})$, Navicula (20 to $55 \mu \mathrm{m}$ ) and Amphora (12 to

Table 2. Average (SE) of $\mathrm{n}$ replicate cores $(\mathrm{n}=9$ for Day $0, \mathrm{n}=$ 3 for the other days) of HPLC accessory pigments expressed as ratio to chl a (wt:wt) of the microbial mat exposed to ambient solar radiation (control), shielded from UVBR (reduced UVBR) and from UVR (reduced UVR)

\begin{tabular}{|c|c|c|c|}
\hline & Ambient & $\begin{array}{c}\text { Reduced } \\
\text { UVBR }\end{array}$ & $\begin{array}{l}\text { Reduced } \\
\text { UVR }\end{array}$ \\
\hline \multicolumn{4}{|l|}{$\mathrm{Chl} C_{1+2}$} \\
\hline Day 0 & $0.16(0.00)$ & & \\
\hline Day 35 & $0.18(0.01)$ & $0.20(0.00)$ & $0.19(0.01)$ \\
\hline Day 77 & $0.23(0.01)$ & $0.23(0.01)$ & $0.24(0.01)$ \\
\hline \multicolumn{4}{|c|}{ Fucoxanthin } \\
\hline Day 0 & $0.52(0.02)$ & & \\
\hline Day 35 & $0.55(0.02)$ & $0.58(0.02)$ & $0.59(0.02)$ \\
\hline Day 77 & $0.73(0.05)$ & $0.67(0.00)$ & $0.78(0.01)^{\mathrm{a}}$ \\
\hline \multicolumn{4}{|c|}{ 19'-hexanoyloxyfucoxanthin } \\
\hline Day 0 & $0.06(0.00)$ & & \\
\hline Day 35 & $0.05(0.00)$ & $0.05(0.01)$ & $0.04(0.01)$ \\
\hline Day 77 & $0.05(0.01)$ & $0.04(0.01)$ & $0.07(0.01)$ \\
\hline \multicolumn{4}{|c|}{ Diatoxanthin + Diadinoxanthin } \\
\hline Day 0 & $0.09(0.01)$ & & \\
\hline Day 35 & $0.09(0.01)$ & $0.09(0.00)$ & $0.09(0.00)$ \\
\hline Day 77 & $0.10(0.00)$ & $0.09(0.01)$ & $0.10(0.00)$ \\
\hline \multicolumn{4}{|c|}{$\beta, \beta$-carotene } \\
\hline Day 0 & $0.07(0.00)$ & & \\
\hline Day 35 & $0.06(0.01)$ & $0.06(0.00)$ & $0.05(0.01)$ \\
\hline Day 77 & $0.06(0.00)$ & $0.05(0.00)$ & $0.06(0.00)$ \\
\hline
\end{tabular}


$37 \mu \mathrm{m})$. From approximately $21 \times 10^{9}$ cells m$^{-2}$, the total diatom abundance exhibited a rapid increase in all treatments to reach values ranging between 41 and $59 \times 10^{9}$ cells $\mathrm{m}^{-2}$ on Day 77. During the experiment, there was a significant $(p \leq 0.05)$ treatment effect on diatom abundance. Both shielded treatments resulted in a significant decline (by $42 \%$ ) in the total abundance of diatoms on Day 35 due to the lower number of small unidentified pennates. On Day 77, the total diatom abundance was $43 \%$ higher with UVR screened off than under control.

Over the whole experiment, microalgal biomass (Fig. 5A) and the percentage of pheopigments (ratio of pheopigments to total pigments, i.e. chl a + pheopigments; Fig. 5B) in the control averaged $33 \mathrm{mg} \mathrm{chl} \mathrm{a} \mathrm{m} \mathrm{m}^{-2}$ and $45 \%$, respectively. The microalgal biomass was inversely correlated with the percentage of pheopigments $\left(\mathrm{r}_{\mathrm{s}}=-0.43, \mathrm{p} \leq 0.001\right)$. No other correlation was found with the other biological or physical variables. Result of nested ANOVA revealed significant changes in both the microalgal biomass and the percentage of pheopigments, mainly during the first part of the experiment (Table 3). UVBR screening significantly altered microalgal biomass on Days 21, 35 and 42 (Fig. 5A), but to a lesser extent than did UVR reduction (Table 3). Conversely, the percentage of pheopigments in UVBR-shielded cores increased on Days 14 and 21 as much as under reduced UVR. Microalgal biomass was significantly less (22 to $35 \%$ ) under UVR reduction than under control on Days 7, 21, 28, 35 and 42 (Fig. 5A, Table 3). In contrast, screening of UVR caused a 19 to $28 \%$ enhancement in the percentage of pheopigments on Days 14, 21 and 70. Microalgal bio-

Table 3. Percent variation of microalgal biomass ( $\mathrm{chl}$ a) and percentage of pheopigments (ratio of pheopigments to total pigments, i.e. chl $a+$ pheopigments) between the 3 treat-

ments. Only significant values at $p \leq 0.05$ are presented

\begin{tabular}{|c|c|c|c|}
\hline & $\begin{array}{c}\text { UVBR } \\
\text { vs control }\end{array}$ & $\begin{array}{c}\text { Reduced } \\
\text { UVR } \\
\text { vs control }\end{array}$ & $\begin{array}{c}\text { UVR vs } \\
\text { reduced UVBR }\end{array}$ \\
\hline \multicolumn{4}{|c|}{ Microalgal biomass (\%) } \\
\hline Day 7 & & -30 & \\
\hline Day 21 & -27 & -35 & \\
\hline Day 28 & & -32 & -22 \\
\hline Day 35 & -17 & -29 & \\
\hline Day 42 & -14 & -22 & \\
\hline \multicolumn{4}{|c|}{ Pheopigments (\%) } \\
\hline Day 14 & 15 & 19 & \\
\hline Day 21 & 28 & 28 & \\
\hline Day 28 & & & 33 \\
\hline Day 35 & & & 16 \\
\hline Day 42 & & & 18 \\
\hline Day 70 & & 26 & \\
\hline
\end{tabular}

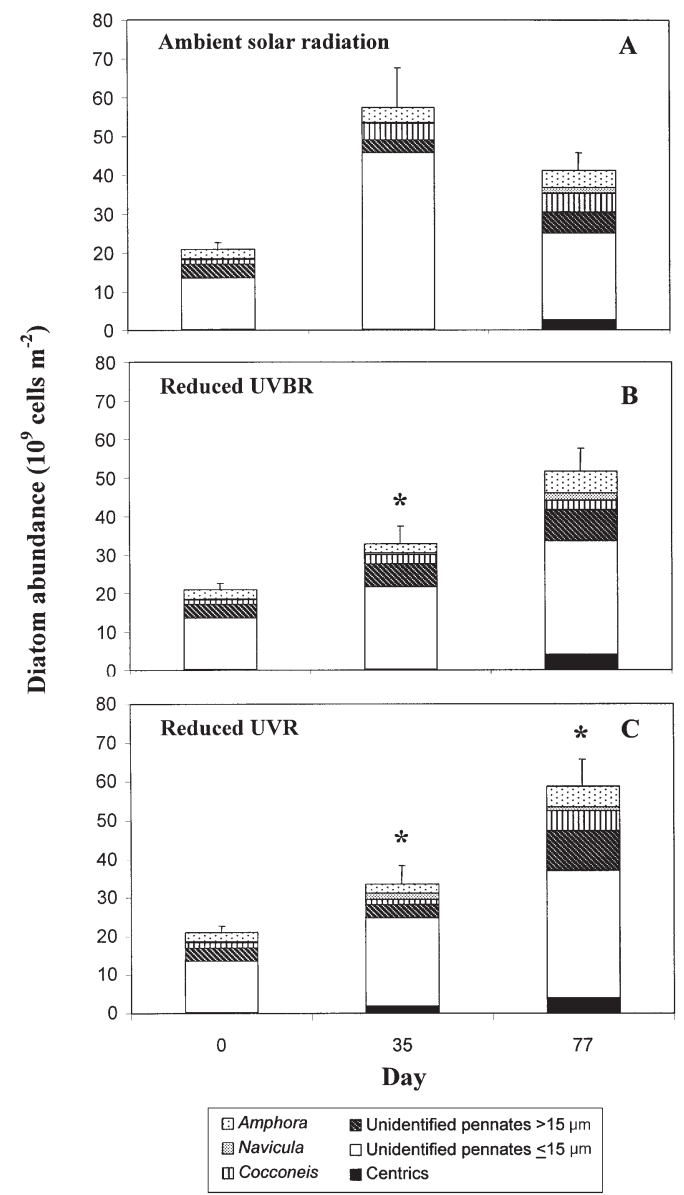

Fig. 4. Composition and abundance of the diatom community of the microbial mat (A) exposed to ambient solar radiation, (B) shielded from UVBR, and (C) shielded from UVR (reduced UVR). Mean $(+\mathrm{SE})$ of $\mathrm{n}$ replicate cores $(\mathrm{n}=9$ for Day $0, n=3$ for the other days) are shown. *Significant difference in cell abundance from the control (ambient solar radiation) $(p \leq 0.05)$

mass was significantly lower under reduced UVR treatment compared to the reduced UVBR treatment on Day 28 (Fig. 5A, Table 3). In contrast, the percentage of pheopigments was significantly higher (16 to $33 \%$ ) in the reduced UVBR treatment on Days 28, 35 and 42 .

During the experiment, the benthic particulate primary production under control varied from 16 to $77 \mathrm{mgC} \mathrm{m}^{-2} \mathrm{~h}^{-1}$ (Fig. 6A) corresponding to 80 to $243 \mathrm{mgC} \mathrm{m}^{-2} \mathrm{~d}^{-1}$. Primary production was directly correlated to both the water temperature $\left(r_{s}=0.88\right.$, $\mathrm{p} \leq 0.001$ ) and incident PAR prevailing during the incubation period $\left(\mathrm{r}_{\mathrm{s}}=0.77, \mathrm{p} \leq 0.001\right)$. A multiple regression test showed that these 2 environmental factors accounted for $79 \%$ of the variance in primary production. Throughout the experiment, less than $3 \%$ of the total (particulate + dissolved) primary production was released to seawater as DOC. The particulate produc- 

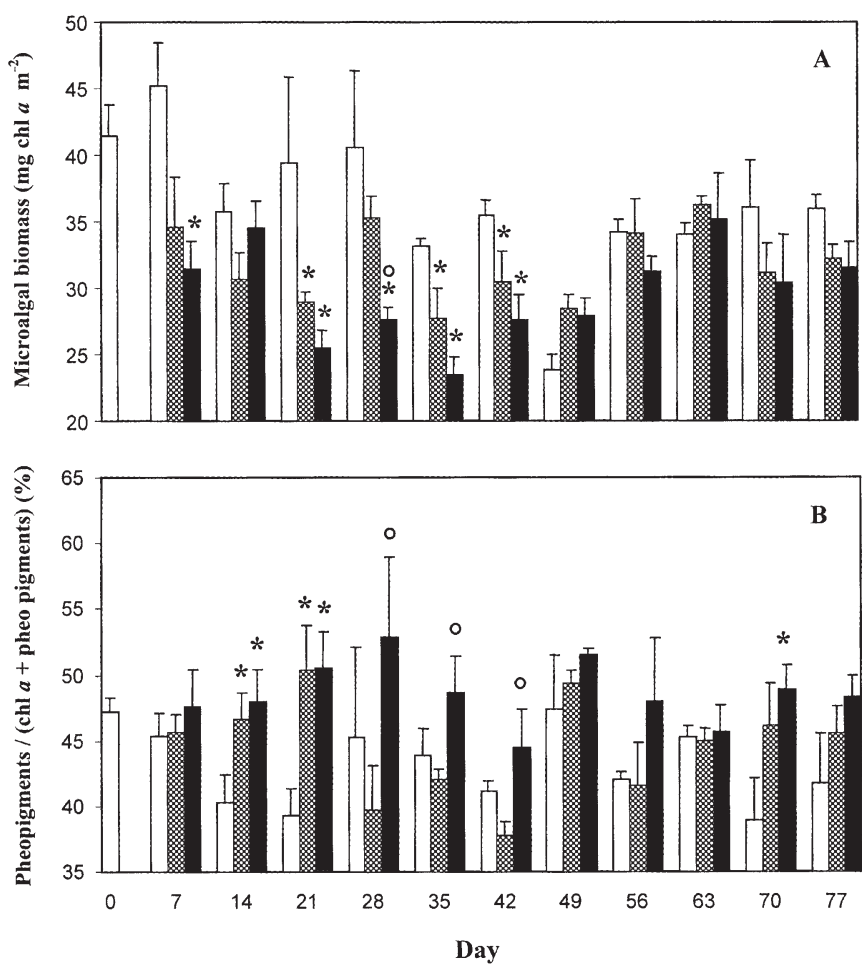

Fig. 5. Temporal variations of (A) microalgal biomass (chl a) and (B) percentage of pheopigments (ratio of pheopigments to total pigments, i.e. chl $a+$ pheopigments) of the microbial mat exposed to ambient solar radiation (white bars), shielded from UVBR (gray bars) and shielded from UVR (black bars). Mean $(+\mathrm{SE})$ of $n$ replicate cores $(n=9$ for Day $0, n=3$ for the other days) are shown. ${ }^{*}$ Significant difference from the control (ambient solar radiation), and $\mathrm{O}$ : significant difference between both shielded treatments $(\mathrm{p} \leq 0.05)$

tion to biomass (P:B) ratio was the only measured variable that was correlated to primary production $\left(\mathrm{r}_{\mathrm{s}}=\right.$ $0.92, \mathrm{p} \leq 0.001)$. A treatment effect was noted on Day 14 when UVR reduction significantly increased carbon fixation by $53 \%$ compared to the control.

At the beginning of the experiment, the average ratio of particulate production to biomass $(\mathrm{P}: \mathrm{B})$ of the benthic microalgae was $1.3 \pm 0.1 \mathrm{mgC} \mathrm{mg} \mathrm{chl} a^{-1} \mathrm{~h}^{-1}$ (Fig. 6B). Over time, the P:B ratio followed a pattern similar to that of particulate primary production. Compared to ambient conditions, UVR screening significantly increased the P:B ratio by $57 \%$ on Day 14 and by $31 \%$ on Day 21.

\section{Meiozoobenthos}

At the beginning of the experiment, nematodes were the most numerous group of meiofauna $(74 \%)$ followed by nauplii $(12 \%)$, copepods $(6 \%)$, copepodites $(4 \%)$, oligochaetes $(3 \%)$ and polychaete larvae $(1 \%)$.
The abundance of the other taxa (turbellarians and foraminiferans) was negligible. Temporal variations in the abundance of nematodes and ontogenic stages of harpacticoid copepods in the different light treatments are presented in Figs $7 \& 8$. Nematode abundance increased gradually from $840 \times 10^{3} \mathrm{~m}^{-2}$ on Day 0 , to around $1600 \times 10^{3} \mathrm{~m}^{-2}$ under control on Day 77 (Fig. 7). After a gradual increase up to Day 28, reaching $265 \times$ $10^{3} \mathrm{~m}^{-2}$ under control, the harpacticoid nauplius abundance declined on Day 35, then peaked on Day 49 before finally decreasing for the remainder of the experiment (Fig. 8A). Copepodite abundance increased from $33 \times 10^{3} \mathrm{~m}^{-2}$ on Day 0 to $167 \times 10^{3} \mathrm{~m}^{-2}$ under control on Day 49 before gradually decreasing for the remainder of the experiment (Fig. 8B). Adult harpacticoid copepod abundance showed a pattern similar to that of copepodites, however the maximum abundance under control occurred on Day 63 (Fig. 8C).

There was some occasional effect of the light regime on meiofaunal abundance (Figs 7 \& 8); however, no consistent pattern was observed. No correlation was found between meiofauna abundance and the other determined variables.
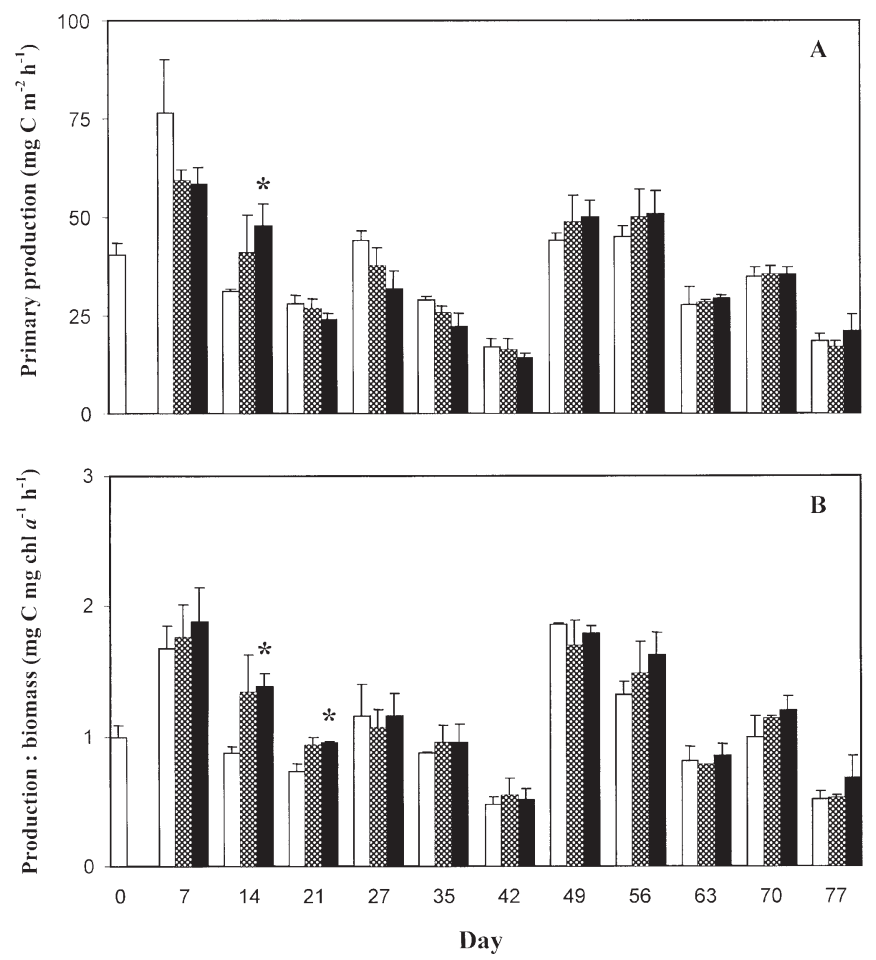

Fig. 6. Temporal variations of (A) primary production and (B) ratio of primary production to algal biomass of the microbial mat exposed to ambient solar radiation (white bars), shielded from UVBR (gray bars) and from UVR (black bars). Mean $(+\mathrm{SE})$ of $\mathrm{n}$ replicate cores $(\mathrm{n}=3$ for the other days) are shown. ${ }^{*}$ Significant difference from the control $(\mathrm{p} \leq 0.05)$ 


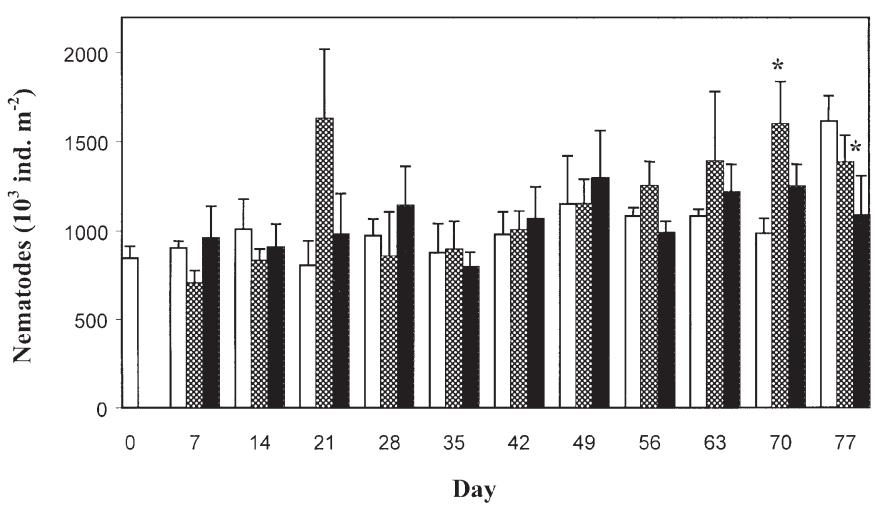

Fig. 7. Temporal variations of nematode abundance in the sediment cores exposed to ambient solar radiation (control, white bars), shielded from UVBR (gray bars) and from UVR (black bars). Mean (+SE) of $n$ replicate cores ( $n=9$ for Day 0 , $\mathrm{n}=3$ for the other days) are shown. ${ }^{*}$ Significant difference from the control $(\mathrm{p} \leq 0.05)$

\section{UVR-absorbing compounds}

Throughout the experiment, the absorbance of methanol extracts presented similar patterns, with 2 absorbance peaks around 270 and $340 \mathrm{~nm}$ (Fig. 9). DNA likely caused the first peak since DNA absorbs wavelengths between 230 and $310 \mathrm{~nm}$ (Buma et al. 1996). The second one is attributed to mycosporinelike amino acids (Dunlap \& Shick 1998). Although no statistical analysis was attempted, the absorbance peaks showed no observable difference between treatments and over time.

\section{DISCUSSION}

\section{The microbenthic community}

There is a long history of investigations into sedimentassociated microalgae colonizing intertidal flats in North America and in Europe (MacIntyre et al. 1996, Cahoon 1999 and references therein). In the St. Lawrence Estuary and Gulf (Canada), only the epilithic component of the microphytobenthos has been studied through an exhaustive taxonomic list (e.g. Cardinal et al. 1984, 1986, Poulin et al. 1984, 1990, Bérard-Therriault et al. 1986, 1987) and through the influence of environmental factors on the community structure (Hudon \& Bourget 1983) and on the photosynthetic properties (Lamontagne et al. 1986, 1989) of epilithic diatoms. In contrast, sedimentassociated microalgae colonizing soft sediment in this region have never been characterized. This study assesses for the first time the summer dynamics of the microphytobenthic community of a muddy intertidal flat in the St. Lawrence Estuary.
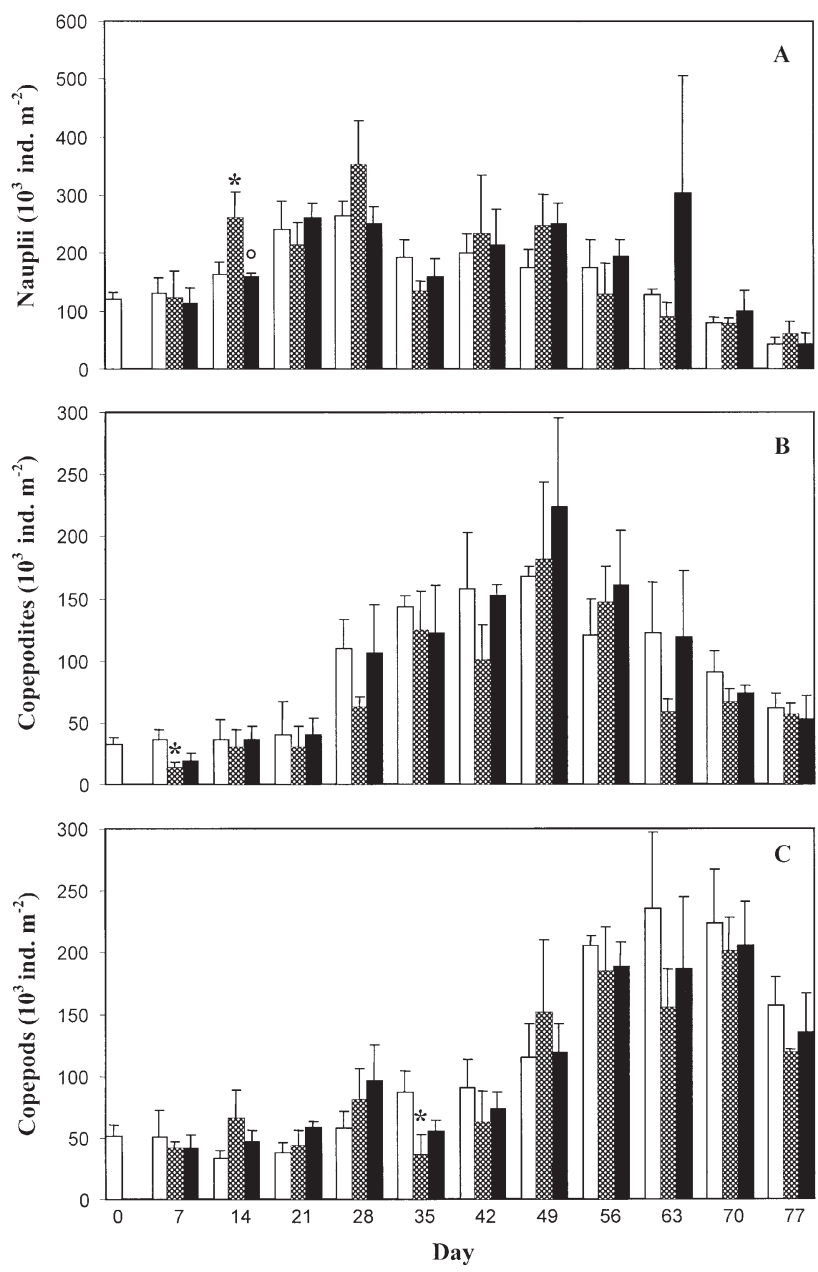

Fig. 8. Temporal variations of (A) nauplius, (B) copepodite and (C) copepod abundances in the sediment cores exposed to ambient solar radiation (white bars), shielded from UVBR (gray bars) and from UVR (black bars). Mean (+SE) of $\mathrm{n}$ replicate cores ( $\mathrm{n}=9$ for Day $0, \mathrm{n}=3$ for the other days) are shown. *Significant difference from the control (ambient solar radiation) and $\mathrm{O}$ : significant difference between both shielded treatments $(\mathrm{p} \leq 0.05)$

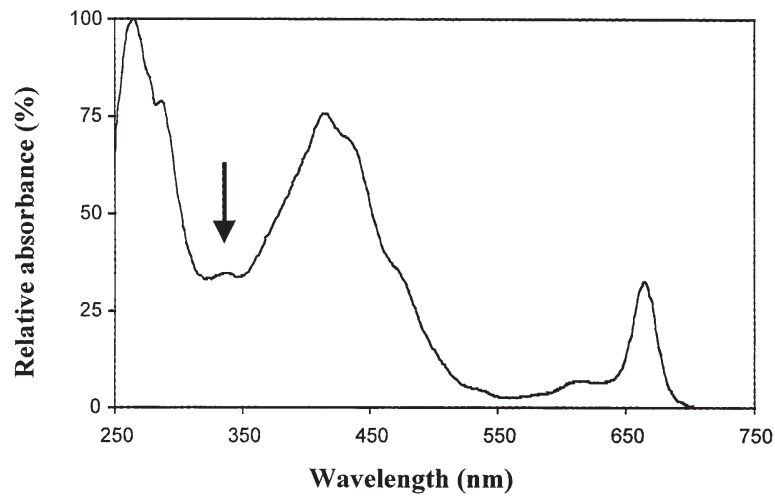

Fig. 9. Typical spectrum of a methanol extract of the microbial mat showing presence of UVR absorbing compounds (arrow) 
Although microphytobenthos in intertidal flats present successional patterns throughout the year (Pinckney et al. 1995, Barranguet et al. 1997), these areas are usually dominated by diatoms (Leach 1970, Cammen \& Walker 1986, Gould \& Gallagher 1990, Sundbäck et al. 1996c, Barranguet et al. 1997). In the present work, HPLCbased accessory pigment signature clearly established the dominance of diatoms within the algal community (Table 2). The carotenoid fucoxanthin was the predominant accessory pigment found along with chl $c_{1+2}$, diadinoxanthin, diatoxanthin and $\beta, \beta$-carotene. These pigments are all found in Bacillariophyceae (Stauber \& Jeffrey 1988). Microscopical examination confirmed the occurrence of benthic diatoms in significant numbers, particularly small $(\leq 15 \mu \mathrm{m})$ pennates (Fig. 4). The main genera identified were Amphora, Navicula and Cocconeis. Flagellates found in small number were likely Prymnesiophyceae since 19'-hexanoyloxyfucoxanthin and the above pigments commonly occur in these taxa (Gieskes \& Kraay 1986, Wright \& Jeffrey 1987).

Benthic microalgal primary production and biomass values can be compared with those of other intertidal flats on the East coast of North America and in Europe (MacIntyre et al. 1996, Cahoon 1999 and references therein). Benthic primary production exhibited large temporal variations (from 16 to $77 \mathrm{mg} \mathrm{C} \mathrm{m}^{-2} \mathrm{~h}^{-1}$, corresponding to 80 to $243 \mathrm{mg} \mathrm{C} \mathrm{m}^{-2} \mathrm{~d}^{-1}$ ) as a result of changes in cloud cover and water temperature during the incubation stage (Fig. 6A). These rates are consistent with those published (from 8 to $175 \mathrm{mgC} \mathrm{m}^{-2} \mathrm{~h}^{-1}$ ) for the East coast of the United States and in Northern Europe (Cahoon 1999). A the end of the experiment, the microalgal production and biomass at the sampling site were $44 \mathrm{mgC} \mathrm{m}^{-2} \mathrm{~h}^{-1}$ and $17 \mathrm{mg} \mathrm{chla} \mathrm{m}^{-2}$ respectively, similar to those measured in the microcosms. Under natural light conditions, microalgal biomass in the top 2 to $3 \mathrm{~mm}$ of the sediment varied from 24 to $45 \mathrm{mg} \mathrm{chla} \mathrm{m}^{-2}$ (Fig. 5A). These values are within the concentration range (15 to $220 \mathrm{mg} \mathrm{chl} \mathrm{a} \mathrm{m}^{-2}$ ) previously reported in North America (Cahoon 1999).

In coastal environments, the growth of shallowwater microphytobenthos is generally not limited by inorganic nutrients because of high rates of remineralization within the sediment (Admiraal et al. 1982, Sundbäck et al. 1996a, but see also Nilsson et al. 1991). In the present study, the nutrient concentration of the overlying water of the microcosms probably did not limit microphytobenthic growth. The high initial values were probably due to the release of inorganic nutrients by the intact sediment cores when placed into the microcosms. Nutrient concentrations rapidly reached values corresponding to a nutrient-depleted sea surface in the lower St. Lawrence Estuary during summer (Levasseur \& Therriault 1987). Ratios of DIN to $\mathrm{Si}(\mathrm{OH})_{4}$ and DIN to $\mathrm{PO}_{4}{ }^{3-}$ were always lower than the critical values of Redfield et al. (1963) of 1 and 16 respectively, suggesting that DIN was the element in shortest supply relative to nutrient requirements of the microalgae (Table 1). However, since the P:B ratio was not correlated with DIN concentration, nutrient limitation probably did not occur in the microcosms. This idea is also supported by the fact that the POC:PON molar ratio in the top 2 to $3 \mathrm{~mm}$ of sediment remained constant (around 11.5) throughout the experiment.

Significant changes over time, irrespective of treatment, were found in the structure of the copepod community. The similar and delayed temporal variations of nauplii, copepodite and copepod abundance corresponded to the normal ontogenic evolution of harpacticoids (Fig. 8). Nauplius abundance increased from Day 0 to 28 as a result of the production of eggs by mature adult copepods and the lack of predators (i.e. polychaetes) which were manually removed. In the Parc du Bic, predation on harpacticoids by Nereis virens is substantial (Tita et al. 2000). Shrimps (Gregg \& Fleeger 1998) and juvenile fishes (Morris \& Coull 1992) can also be voracious predators of nauplii. The sudden decrease in nauplius abundance on Day 35 was probably related to recruitment into the copepodite stage, leading to enhanced copepodite and copepod abundance in the middle and end of the experiment, respectively. The nauplius abundance peak on Day 49, 21 d after the first peak on Day 28, probably reflected the occurrence of a second nauplius cohort (Fig. 8A). Palmer \& Coull (1980) found, from a laboratory study, that the development time for the nauplius stage of Microarthridion littorale lasts from $30 \mathrm{~d}$ at $15^{\circ} \mathrm{C}$ to $20 \mathrm{~d}$ at $25^{\circ} \mathrm{C}$. Yet, a second peak in copepodite abundance was not observed, which suggests that an increase in the nauplius mortality, as a result of food limitation in the microcosms, prevented the appearance of another abundance peak in copepodite population. As consumers, harpacticoid copepods feed on both planktonic and benthic diatoms, autotrophic flagellates, bacteria and detritus (Hicks \& Coull 1983). It is known that they can regulate their behavior to maximize the intake of food (Montagna et al. 1995). Evidence of feeding differences among species (Pace \& Carman 1996) and ontogenic stages (Decho \& Fleeger 1988) suggests that meiobenthic copepods require a rather specialized food source. Therefore, a qualitative impoverishment of food for harpacticoid notably nauplii, was certainly possible since there was no external food contribution in the microcosms.

\section{Treatment effects}

Results of investigations into the effects of UVR on benthic fauna inhabiting shallow waters vary consider- 
ably because of temporal and spatial disparity in both UVR exposure and organism sensitivity (Hill et al. 1997). Many studies have demonstrated that grazers are unaffected by UVR exposure (DeNicola \& Hoagland 1996, Sundbäck et al. 1996b, 1997, Hill et al. 1997, Vinebrooke \& Leavitt 1999). Our study agrees with these earlier experiments since we did not find any significant pattern of treatment effect on meiofauna, neither on nematode nor on ontogenic stages of harpacticoid copepod abundances. The burrowing activity of both nematodes (Heip et al. 1985) and harpacticoids (Hicks \& Coull 1983) within the sediment likely contributed to reducing the UVR exposure. Conversely, Nozais et al. (1999) reported that the larval stages (nauplii and copepodites) of harpacticoid copepods could be susceptible to ambient levels of UVBR in the St. Lawrence Estuary. The same pattern did not occur in the present study. This could be attributed to the fact that sampling the top $2 \mathrm{~cm}$ of the sediment might have masked the effects of UVR on nauplii and copepodites living at the water-sediment interface. Another possible explanation is related to the UVBR levels. Due to technical problems, we did not record UVBR values and were forced to use the UVBR to UVAR ratio calculated by Nozais et al. (1999) to estimate UVBR. These levels may have been lower during the present experiment, perhaps resulting in the absence of UVR effects on larval stages of harpacticoid copepods.

A number of studies have demonstrated that ambient ultraviolet radiation inhibits photosynthesis of both planktonic (Smith et al. 1992, Mostajir et al. 1999b) and benthic (Sundbäck et al. 1997, Odmark et al. 1998) microalgae. The present experiment corroborates these earlier reports since UVR reduction resulted in an enhanced P:B ratio of microphytobenthos on 2 consecutive sampling days in July (Fig. 6B). This suggests a detrimental but weak effect of ambient UVR on photosynthesis. The fact that both UVBR and UVAR were simultaneously responsible for the declining chl $a$ specific photosynthetic activity corroborates the biological weighting function of Cullen et al. (1992) showing that both UVBR and UVAR wavebands inhibit the photosynthesis of diatoms (Fig. 2B). Cockell \& Rothschild (1999) also noted that both UVBR and UVAR acted simultaneously as a stress source for some benthic microbial mats.

During the first part of the experiment, we found a stepwise decrease in microalgal biomass when UVBR and UVR were screened out (Fig. 5A). Conversely, the percentage of pheopigments increased under both shielded treatments (Fig. 5B). These results are in agreement with those of Odmark et al. (1998), who reported an increase of chl a concentration under ambient solar radiation compared to UVBR reduction. Bothwell et al. (1994) also found that algal biomass accumulated in streams exposed to ambient solar radiation compared to reduced UVR. They attributed this periphyton accrual to the elimination of macrograzers. The fact that the 2 shielded treatments provoked a differential treatment response in chl a accrual and in the percentage of pheopigments suggests an enhanced grazing pressure in shielded sediment cores. The abundance of meiofauna was not disrupted by treatments. As discussed above, the sampling depth for studying meiofauna may have masked UVR effects on nauplius and copepodite abundance and therefore grazing rates. Besides, it is known that benthic microfauna (e.g. heterotrophic flagellates and ciliates) feed on microphytobenthos. For example, up to $10 \%$ of the total daily benthic primary production can be grazed by ciliates (Epstein et al. 1992). In the lower St. Lawrence Estuary, abundance and grazing rates of planktonic ciliates have been shown to be enhanced under reduced UVR conditions (Mostajir et al. 1999a). Along the same line, we hypothesize that sediment-associated microfauna were also affected by UVR during our study. Future research on the effect of UVR on benthic systems should include measurements of grazing rates of both microfauna and meiofauna.

Significant changes in the abundance of diatoms were found throughout the experiment. The decrease in the total diatom abundance in shielded cores on Day 35 supports the idea of an enhanced grazing pressure under these treatments (Fig. 4). However, these results contrast with those observed on Day 77. The enhanced diatom abundance on Day 77 in protected cores may reflect the enhanced P:B ratio at the end of the experiment. Although we did not find such effects statistically, the last $4 \mathrm{wk}$ of the study were characterized by tendencies of increased microalgal P:B ratio under reduced UVR treatment (Fig. 6B). The fact that only the small unidentified pennate diatoms were affected by UVR reduction on Day 35 suggests, as formerly demonstrated by Santas et al. (1997), different UVR susceptibility within the diatom community.

\section{Attenuation of UVR damage}

The different strategies used by organisms for the minimization of UVR-induced damage are described in Roy (2000). Benthic microalgae can avoid UVR fluxes by migrating downward in the sediment since vertical migration offers substantial protection for cyanobacteria against UVR exposure (Nadeau et al. 1999). Although this behavioral process probably applies for diatoms (Sundbäck et al. 1996b), its longterm efficiency is doubtful (Underwood et al. 1999). Attenuation of UVR-induced impairments can also be achieved through the synthesis of various cellular com- 
ponents absorbing in the UVR band. Our methanol extracts revealed UVR-absorbing compounds probably containing MAAs since they absorb wavelengths between 310 and $360 \mathrm{~nm}$ (Karentz et al. 1991) (Fig. 9). The occurrence of very low concentrations of UVRabsorbing compounds in our samples is consistent with the fact that diatom-dominated microbial mats usually accumulate very small amounts of UVR-absorbing compounds (Sundbäck et al. 1996b, 1997). Instead, microalgae may rely on other UVR-protective mechanisms such as an efficient UVR-induced damage repair system, as suggested by Peletier et al. (1996). Carotenoid pigments are also involved in photoprotection. For example, $\beta, \beta$-carotene acts as a quenching system against free radicals produced by UVR exposure (Burton \& Ingold 1984). Underwood et al. (1999) noted that benthic diatoms increased their $\beta, \beta$-carotene concentration when faced with enhanced UVBR exposure. We found no significant difference between treatments for the $\beta, \beta$-carotene to chl a ratio (Table 2 ). Nor did we find a significant difference in the ratio of photoprotective pigments (diadinoxanthin + diatoxanthin) to chl a between treatments. Although the de-epoxidation of diadinoxanthin to diatoxanthin can play a photoprotective role when algal cells are exposed to excessive PAR light (Demers et al. 1991), its protection against UVBR and UVR has not been demonstrated in diatomdominated microphytobenthic communities (Sundbäck et al. 1996b, Wulff et al. 1999, 2000). Finally, the total organic material in the seawater overlying the sediment might have provided some protection for the epibenthic organisms, especially at high tide. During our experiment, the concentration of total organic carbon (TOC) in the water column averaged $161 \mu \mathrm{M}$. UVR absorption by the chromophoric dissolved organic matter (CDOM) component of TOC can be high in the lower St. Lawrence Estuary (Whitehead et al. 2000).

\section{Treatment effect and nutritional status}

In contrast to planktonic communities, effects of nutrient supply on the response of benthic communities to changes in UVR have been poorly investigated. In a marine microtidal area of Sweden, Wulff et al. (2000) observed that nutrient limitation increased the sensitivity of benthic microalgae to ambient UVBR. The fact that we observed UVR effects on the microalgal P:B ratio despite the probable availability of inorganic nutrients implies that nutrient limitation is not a necessary condition to witness UVR effects in the St. Lawrence Estuary. Likewise, the UVR-susceptibility of some periphytonic communities inhabiting Canada's streams was not related to their nutritional status (Bothwell et al. 1993).

\section{UVBR versus UVAR effects}

Both UVBR and UVAR were simultaneously studied in this experiment, thereby allowing for distinction between the effects of these 2 solar UV components. The enhanced microalgal P:B ratio on Days 14 and 21 in UVR-protected cores (Fig. 6B) indicates that both solar ultraviolet components are simultaneously responsible for the treatment effect. In addition, very noticeable changes in chl a accrual and in the percentage of pheopigments were observed between reduced UVBR treatment and control, and between both protected treatments. This implies that UVBR and UVAR are separately responsible for these changes in the microphytobenthic community. UVBR is well recognized as an important stress factor for many benthic communities (Nozais et al. 1999, Wulff et al. 2000). Similarly, UVAR can provoke direct inhibition of algal growth and photosynthesis in Canada's streams (Bothwell et al. 1994). UVAR can also affect microalgae through the consumer level ('the solar cascade', Williamson 1995). Indeed, Bothwell et al. (1994) argued that UVAR can enhance periphyton accrual through elimination of macrograzer populations (e.g. larval chironomids). In contrast, Wulff et al. (1999) reported from a 4 mo field experiment that ambient UVAR did not exert any selective pressure on the overall microbenthic community in a shallow water of a microtidal sandy bay on the west coast of Sweden.

\section{Short-term versus long-term effects}

Compared to the first part of the experiment (early summer), a noticeable lack of UVR effects were noted during the second half of the study (late summer). We hypothesize that the high UVR fluxes at the beginning of the experiment enhanced the rate of photodamage relative to that of photorepair, resulting in the decreasing microalgal P:B ratio on Days 14 and 21. Then, as the summer progressed, ambient UVR fluxes decreased, resulting in a greater proportion in the rate of photorepair which eliminated the detrimental effect of UVR on the photosynthetic apparatus. Studying a planktonic community, Furgal \& Smith (1997) concluded that the inhibition of photosynthesis by ambient UVBR was proportional to the seasonal variation of UVBR fluxes. Similarly, the decreasing seasonal UVR fluxes may also have softened the UVR-susceptibility of herbivorous grazers.

\section{CONCLUSIONS}

In summary, the reduction of UVR resulted in an enhancement of primary production normalized to 
chl a on 2 consecutive sampling days in July, when daily incident irradiances were at their seasonal maximum. This suggests a detrimental but weak direct effect of UVR on photosynthesis. In addition, the decreased chl a concentration and diatom abundance in UVR-shielded treatments and the simultaneous increase in the percentage of pheopigments suggest an enhanced grazing pressure under these treatments. The lack of treatment effects during the second half of the experiment in late summer may be due to the decreasing UVR daily fluxes as per seasonal trends. Our results finally indicate that UVAR plays a role as important as UVBR on microphytobenthic photosynthesis and biomass, and presumably on microfauna grazing activity. Future experiments should be designed to test the influence of UV radiation on the grazing activity of microzoobenthos. Natural and seminatural experiments considering the macrozoobenthic compartment are also needed in order to improve our understanding of how microphytobenthos will respond to future changes in ambient UVBR fluxes and in the spectral balance (ratio of UVBR over PAR + UVAR + UVBR).

Acknowledgements. This research was funded by grants from Fonds pour la Formation des chercheurs et l'aide à la recherche (Fonds FCAR) of Quebec, Fondation de l'Université du Québec à Rimouski (FUQAR) and Natural Sciences and Engineering Research Council (NSERC) of Canada. R.R. was supported by a graduate stipend from FUQAR and Fonds FCAR. We thank Mélanie Simard for the algal counts; Line McLaughlin and Marie-Lyne Dubé for nutrient analysis; Diane Bérubé for CHN analysis; Robert F. Whitehead for TOC analysis; Bryan J. Weissenboeck and José Sara for improving English; Suzanne Roy, Serge Demers and 2 anonymous referees for insightful comments on the manuscript. This research is in partial fulfillment of R.R.'s Masters degree at UQAR and is a contribution of the research programs of ISMER.

\section{LITERATURE CITED}

Admiraal W, Peletier H, Zomer H (1982) Observations and experiments on the population of epipelic diatoms of an estuarine mudflat. Estuar Coast Shelf Sci 14:471-487

Arrigo KR (1994) Impact of ozone depletion on phytoplankton growth in the Southern Ocean: large-scale spatial and temporal variability. Mar Ecol Prog Ser 114:1-12

Barranguet C, Herman PMJ, Sinke JJ (1997) Microphytobenthos biomass and community composition studied by pigment biomarkers: importance and fate in the carbon cycle of a tidal flat. J Sea Res 38:59-70

Bérard-Therriault L, Cardinal A, Poulin M (1986) Les diatomées (Bacillariophyceae) benthiques de substrats durs des eaux marines et saumâtres du Québec. 6. Naviculales: Cymbellaceae et Gomphonemaceae. Naturaliste Can 113: 405-429

Bérard-Therriault L, Cardinal A, Poulin M (1987) Les diatomées (Bacillariophyceae) benthiques de substrats durs des eaux marines et saumâtres du Québec. 8. Centrales. Naturaliste Can 114:81-113
Blumthaler M, Ambach W (1990) Indication of increasing solar ultraviolet-B radiation flux in alpine regions. Science 248:206-208

Bothwell ML, Roberge AC, Daley RJ (1993) Influence of natural ultraviolet radiation on lotic periphytic diatom community growth, biomass accrual, and species composition: short-term versus long-term effects. J Phycol 29: 24-35

Bothwell ML, Sherbot MJ, Colleen MP (1994) Ecosystem response to solar ultraviolet-B radiation: influence of trophic-level interactions. Science 265:97-100

Buma AGJ, van Hannen EJ, Veldhuis MJW, Gieskes WWC (1996) UV-B induces DNA damage and DNA synthesis delay in the marine diatom Cyclotella sp. Sci Mar 60: 101-106

Burdige DJ, Homstead J (1994) Fluxes of dissolved organic carbon from Chesapeake Bay sediments. Geochim Cosmochim Acta 58:3407-3424

Burton GW, Ingold KU (1984) $\beta$-carotene: an unusual type of lipid antioxydant. Science 224:569-573

Cahoon LB (1999) The role of benthic microalgae in neritic ecosystems. Oceanogr Mar Biol Annu Rev 37:47-86

Cammen LM, Walker JA (1986) The relationship between bacteria an micro-algae in the sediment of a Bay of Fundy mudflat. Estuar Coast Shelf Sci 22:91-99

Cardinal A, Poulin M, Bérard-Therriault L (1984) Les diatomées benthiques de substrats durs des eaux marines et saumâtres du Québec. 4. Naviculales, Naviculaceae (à l'exclusion des genres Navicula, Donkinia, Gyrosigma et Pleurosigma). Naturaliste Can 111:369-394

Cardinal A, Poulin M, Bérard-Therriault L (1986) Les diatomées benthiques de substrats durs des eaux marines et saumâtres du Québec. 5. Naviculales, Naviculaceae: les genres Navicula, Donkinia, Gyrosigma et Pleurosigma. Naturaliste Can 113:167-190

Cockell SC, Rothschild LJ (1999) The effects of UV radiation $\mathrm{A}$ and $\mathrm{B}$ on diurnal variation in photosynthesis in three taxonomically and ecologically diverse microbial mats. Photochem Photobiol 69:203-210

Cullen JJ, Neale PJ, Lesser MP (1992) Biological weighting function for the inhibition of phytoplankton photosynthesis by ultraviolet radiation. Science 258:646-650

Decho AW, Fleeger JW (1988) Ontogenic feeding shifts in the meiobenthic harpacticoid copepod Nitocra lacustris. Mar Biol 97:191-197

Demers S, Roy S, Gagnon R, Vignault C (1991) Rapid lightinduced changes in cell fluorescence and in xanthophyllcycle pigments of Alexandrium excavatum (Dinophyceae) and Thalassiosira pseudonana (Bacillariophyceae): a photoprotection mechanism. Mar Ecol Prog Ser 76:185-193

DeNicola DM, Hoagland KD (1996) Effects of solar spectral irradiance (visible to UV) on a prairie stream epilithic community. J North Am Benthol Soc 15:155-169

Dionne JC (1977) La mer de Goldthwait au Québec. Geogr Phys Quat 31:61-80

Dunlap WC, Shick JM (1998) Ultraviolet radiation-absorbing mycosporine-like amino acids in coral reef organisms: a biochemical and environmental perspective. J Phycol 34: 418-430

Epstein SS, Burkovsky IV, Shiaris MP (1992) Ciliate grazing on bacteria. flagellates, and microalgae in a temperate zone sandy tidal flat: ingestion rates and food niche partitioning. J Exp Mar Biol Ecol 165:103-123

Farman JC, Gardiner BG, Shanklin JD (1985) Large losses of total ozone in Antarctica reveal seasonal ClOx/NOx interaction. Nature 315:207-210

Furgal JA, Smith REH (1997) Ultraviolet radiation and photo- 
synthesis by Georgian Bay phytoplankton of varying nutrient and photoadaptative status. Can J Fish Aquat Sci 54:1659-1667

Garcia-Pichel F, Bebout BM (1996) Penetration of ultraviolet radiation into shallow water sediments: high exposure for photosynthetic communities. Mar Ecol Prog Ser 131:257-262

Gieskes WWC, Kraay GW (1986) Floristic and physiological differences between the shallow and the deep nanophytoplankton community in the euphotic zone of the open tropical Atlantic revealed by HPLC analysis of pigments. Mar Biol 91:567-576

Godin G (1979) La marée dans le golfe et l'estuaire du SaintLaurent. Naturaliste Can 106:105-121

Gould DM, Gallagher ED (1990) Field measurements of specific growth rate, biomass and primary production of benthic diatoms of Savin Hill Cove, Boston. Limnol Oceanogr 35:1757-1770

Gregg CS, Fleeger JW (1998) Grass shrimp Palaemonetes pugio on sediment- and stem-dwelling meiofauna: field and laboratory experiments. Mar Ecol Prog Ser 175:77-86

Heip C, Vincx M, Vranken G (1985) The ecology of marine nematodes. Oceanogr Mar Biol Ann Rev 23:399-489

Helbling EW, Villafañe VE, Ferrario M, Holm-Hansen O (1992) Impact of natural ultraviolet radiation on rates of photosynthesis and on specific marine phytoplankton species. Mar Ecol Prog Ser 80:89-100

Hicks GRG, Coull BC (1983) The ecology of marine meiobenthic harpacticoid copepods. Oceanogr Mar Biol Annu Rev 21:67-175

Hill WR, Dimick SM, McNamara AE, Branson CA (1997) No effects of ambient UV radiation detected in periphyton and grazers. Limnol Oceanogr 42:769-774

Hofmann DJ (1996) The 1996 Antarctic ozone hole. Nature 383:129

Hudon C, Bourget E (1983) The effect of light on the vertical structure of epibenthic diatom communities. Bot Mar 26: 317-330

Karentz D, McEuen FS, Land MC, Dunlap WC (1991) Survey of mycosporine-like amino acid compounds in Antarctic marine organisms: potential protection from ultraviolet exposure. Mar Biol 108:157-166

Kerr JB, McElroy CT (1993) Evidence for large upward trends of ultraviolet-B radiation linked to ozone depletion. Science 262:1032-1034

Kirk JTO (1994) Optics of UV-B radiation in natural waters. Arch Hydrobiol Beih 43:1-16

Lamontagne I, Cardinal A, Fortier L (1986) Intertidal microalgal production and the auxiliary energy of tides. Mar Biol 91:409-419

Lamontagne I, Cardinal A, Fortier L (1989) Environmental forcing versus endogenous control of photosynthesis in intertidal epilithic microalgae. Mar Ecol Prog Ser 51: $177-187$

Leach JH (1970) Epibenthic algal production in an intertidal mudflat. Limnol Oceanogr 15:514-521

Lean DRS, Burnison BK (1979) An evaluation of errors in the ${ }^{14} \mathrm{C}$ method of primary production measurement. Limnol Oceanogr 24:917-928

Legendre L, Demers S, Yentsch CM, Yentsch CS (1983) The ${ }^{14} \mathrm{C}$ method: patterns of dark fixation and DCMU correction to replace the dark bottle. Limnol Oceanogr 28: 996-1003

Levasseur ME, Therriault JC (1987) Phytoplankton biomass and nutrient dynamics in a tidally induced upwelling: the role of the $\mathrm{NO}_{3}: \mathrm{SiO}_{4}$ ratio. Mar Ecol Prog Ser 39:87-97

Lund JWG, Kipling C, Le Cren ED (1958) The inverted microscope method of estimating algal numbers and the statisti- cal basis of estimations by counting. Hydrobiologia 11: $143-170$

MacIntyre HL, Geider RJ, Miller DC (1996) Microphytobenthos: the ecological role of the 'Secret Garden' of unvegetated, shallow-water marine habitats. I. Distribution, abundance and primary production. Estuaries 19:186-201

Miller DC, Geider RJ, MacIntyre HL (1996) Microphytobenthos: the ecological role of the 'Secret Garden' of unvegetated, shallow-water marine habitats. II. Role in sediment stability and shallow-water food webs. Estuaries 19: 202-212

Moeller RE (1994) Contribution of ultraviolet radiation (UV-A, UV-B) to photoinhibition of epilimnetic phytoplankton in lakes of differing UV transparency. Arch Hydrobiol Beih 43:157-170

Montagna PA, Blanchard GF, Dinet A (1995) Effects of production and biomass of intertidal microphytobenthos on meiofaunal grazing rates. J Exp Mar Biol Ecol 185: $149-165$

Morris JT, Coull BC (1992) Population dynamics, numerical production, and potential predation impact on a meiobenthic copepod. Can J Fish Aquat Sci 49:609-616

Mostajir B, Demers S, de Mora S, Belzile C and 6 others (1999a) Experimental test of the effects of ultraviolet-B radiation in a planktonic community. Limnol Oceanogr 44 : 586-596

Mostajir B, Sime-Ngando T, Demers S, Belzile C and 7 others (1999b) Ecological implications of changes in cell size and photosynthetic capacity of marine Prymnesiophyceae induced by ultraviolet-B radiation. Mar Ecol Prog Ser 187: 89-100

Mostajir B, Demers S, de Mora S, Bukata S, Jerome JH (2000) Implications of UV radiation for the food web structure and consequences on the carbon flow. Cambridge Environmental Chemistry series 11, Cambridge University Press, Cambridge, p 310-320

Müller R, Crutzen PJ, Groob JU, Brühl C, Russel JM III, Gernandt H, McKenna DS, Tuck AF (1997) Severe chemical ozone loss in the Arctic during the winter of 1995-96. Nature 389:709-712

Nadeau TL, Howard-Williams C, Castenholz RW (1999) Effects of solar UV and visible irradiance on photosynthesis and vertical migration of Oscillatoria sp. (Cyanobacteria) in an Antarctic microbial mat. Aquat Microb Ecol 20: 231-243

Nilsson P, Jönsson B, Swanberg IL, Sundbäck K (1991) Response of a marine shallow-water sediment system to an increased load of inorganic nutrients. Mar Ecol Prog Ser 71:275-290

Nozais C, Desrosiers G, Gosselin M, Belzile C, Demers S (1999) Effects of ambient UVB radiation in a meiobenthic community of a tidal mudflat. Mar Ecol Prog Ser 189: $149-158$

Odmark S, Wulff A, Wängberg SÅ, Nilsson C, Sundbäck K (1998) Effects of UVB radiation in a microbenthic community of a marine shallow-water sandy sediment. Mar Biol 132:335-345

Pace MC, Carman KR (1996) Interspecific differences among meiobenthic copepods in the use of microalgal food resources. Mar Ecol Prog Ser 143:77-86

Palmer MA, Coull BC (1980) The prediction of development rate and the effect of temperature for the meiobenthic copepod, Microarthridion littorale. J Exp Mar Biol Ecol 48: 73-83

Parsons TR, Maita Y, Lalli CM (1984) A manual of chemical and biological methods for seawater analysis. Pergamon Press, Toronto 
Peletier H, Gieskes WWC, Buma AGJ (1996) Ultraviolet-B radiation resistance of benthic diatoms isolated from tidal flats in the Dutch Wadden Sea. Mar Ecol Prog Ser 135: 163-168

Pinckney J, Paerl HW, Fitzpatrick M (1995) Impacts of seasonality and nutrients on microbial mat community structure and function. Mar Ecol Prog Ser 123:207-216

Poulin M, Bérard-Therriault L, Cardinal A (1984) Les diatomées benthiques de substrats durs des eaux marines et saumâtres du Québec. 3. Fragilarioideae (Fragilariales, Fragilariaceae). Naturaliste Can 111:349-367

Poulin M, Bérard-Therriault L, Cardinal A, Hamilton PB (1990) Les diatomées (Bacillariophyta) benthiques de substrats durs des eaux marines et saumâtres du Québec. 9. Bacillariaceae. Naturaliste Can 117:73-101

Randel JR, Wu F (1999) A stratospheric ozone trends data set for global modelling studies. Geophys Res Lett 26: 3089-3092

Redfield AC, Ketchum BH, Richards FA (1963) The influence of organisms on the composition of sea-water. In: Hill MN (ed) The sea, Vol 2. Interscience, New York, p 26-77

Rex M, Harris NRP, von der Gathen P, Lehmann R and 20 others (1997) Prolonged stratospheric ozone loss in the 1995-96 Arctic winter. Nature 389:835-838

Riaux-Gobin C, Klein B (1993) Microphytobenthic biomass measurement using HPLC and conventional pigments analysis. In: Kemp P, Sherr B, Sherr E, Cole J (eds) Handbook of methods in aquatic microbial ecology. Lewis Publishers, Boca Raton, p 369-376

Roy S (2000) Strategies for the minimisation of UV-induced damage. In: de Mora S, Demers S, Vernet M (eds) The effects of UV radiation in the marine environment. Cambridge Environmental Chemistry series 10, Cambridge University Press, Cambridge, p 177-205

Roy S, Chanut JP, Gosselin M, Sime-Ngando T (1996) Characterization of phytoplankton communities in the lower St. Lawrence Estuary using HPLC-detected pigments and cell microscopy. Mar Ecol Prog Ser 142:55-73

Santas R, Lianou C, Danielidis D (1997) UVB radiation and depth interaction during primary succession of marine diatom assemblages of Greece. Limnol Oceanogr 42: 986-991

Smith RC, Prézelin BB, Baker KS, Bidigare RR and 9 others (1992). Ozone depletion: ultraviolet radiation and phytoplankton biology in Antarctic waters. Science 255:952-959

Solórzano L (1969) Determination of ammonia in natural waters by the phenolhypochlorite method. Limnol Oceanogr 14:799-801

Sommaruga R, Obernosterer I, Herndl GJ, Psenner R (1997) Inhibitory effect of solar radiation on thymidine and leucine incorporation by freshwater and marine bacterioplankton. Appl Environ Microbiol 63:4178-4184

Stauber JL, Jeffrey SW (1988) Photosynthetic pigments in 51 species of marine diatoms. J Phycol 24:158-172

Strickland JDH, Parsons TR (1972) A practical handbook of seawater analysis. Bull Fish Res Board Can 167:1-310

Sundbäck K, Carlson L, Nilsson C, Jönsson B, Wulff A, Odmark S (1996a) Response of benthic microbial mats to drifting green algal mats. Aquat Microb Ecol 10:195-208

Sundbäck K, Nilsson C, Odmark S, Wulf A (1996b) Does ambient UVB radiation influence marine diatom-dominated microbial mats? A case study. Aquat Microb Ecol 11: $151-159$

Editorial responsibility: Otto Kinne (Editor),

Oldendorf/Luhe, Germany
Sundbäck K, Nilsson P, Nilsson C, Jönsson B (1996c) Balance between autotrophic and heterotrophic components and processes in microbenthic communities of sandy sediments: a field study. Estuar Coast Sci 43:689-706

Sundbäck K, Odmark S, Wulff A, Nilsson C, Wängberg SA (1997) Effects of enhanced UVB radiation on a marine benthic diatom mat. Mar Biol 128:171-179

Tita G (1999) La méiofaune de la région estuarienne du SaintLaurent (Québec, Canada): zone intertidale (Parc du Bic) et zone subtidale (Fjord du Saguenay). PhD thesis, Université du Québec à Rimouski

Tita G, Desrosiers G, Vincx M, Nozais C (2000) Predation and sediment disturbance effects of the intertidal polychaete Nereis virens (Sars) on associated meiofaunal assemblages. J Exp Mar Biol Ecol 243:261-282

Thorin S, Bourdages H, Vincent B (1998) Study of siphon activity in Mya arenaria (L.) in the intertidal zone by means of an underwater video camera. J Exp Mar Biol Ecol 224:205-224

Underwood AJ (1981) Techniques of analysis of variance in experimental marine biology and ecology. Oceanogr Mar Biol Annu Rev 19:513-605

Underwood GJC, Kromkamp J (1999) Primary production by phytoplankton and microphytobenthos in estuaries. In: Nedwell DB, Raffaelli DG (eds) Estuaries: advances in ecological research, Vol 29. Academic Press, San Diego, p 93-153

Underwood GJC, Nilsson C, Sundbäck K, Wulff A (1999) Short-term effects of UVB radiation on chlorophyll fluorescence, biomass, pigments, and carbohydrate fractions in a benthic diatom mat. J Phycol 35:656-666

Vincent WF, Roy S (1993) Solar ultraviolet-B radiation and aquatic primary production: damage, protection and recovery. Environ Rev 1:1-12

Vinebrooke RD, Leavitt P (1996) Effects of UV radiation on periphyton in an alpine lake. Limnol Oceanogr 41: $1035-1040$

Vinebrooke RD, Leavitt P (1999) Differential responses of littoral communities to ultraviolet radiation in an alpine lake. Ecology 80:223-237

Whitehead RF, de Mora S, Demers S, Gosselin M, Monfort P, Mostajir B (2000) Interactions of ultraviolet-B radiation, mixing, and biological activity on photobleaching of natural chromophoric dissolved organic matter: a mesocosm study. Limnol Oceanogr 45:278-291

Williamson CE (1995) What role does UV-B radiation play in freshwater ecosystems? Limnol Oceanogr 40:386-392

Wright SW, Jeffrey SW (1987) Fucoxanthin pigment markers of marine phytoplankton analysed by HPLC and HPTLC. Mar Ecol Prog Ser 38:259-266

Wright SW, Jeffrey SW, Mantoura RFC, Llewellyn CA, Bjørnland T, Repeta D, Welschmeyer N (1991) Improved HPLC method for the analysis of chlorophylls and carotenoids from marine phytoplankton. Mar Ecol Prog Ser 77: 183-196

Wulff A, Nilsson C, Sundbäck K, Wängberg SÅ, Odmark S (1999) UV radiation on microbenthos - a four month field experiment. Aquat Microb Ecol 19:269-278

Wulff A, Wängberg SÅ, Sundbäck K, Nilsson C, Underwood GJC (2000) Effects of UVB radiation on a marine microphytobenthic community growing on a sand-substratum under different nutrient conditions. Limnol Oceanogr 45: $1144-1152$

Submitted: September 18, 2000; Accepted: April 26, 2001 Proofs received from author(s): December 18, 2001 